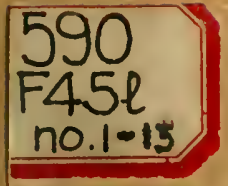

\section{THE WHITE-TAILED DEER}

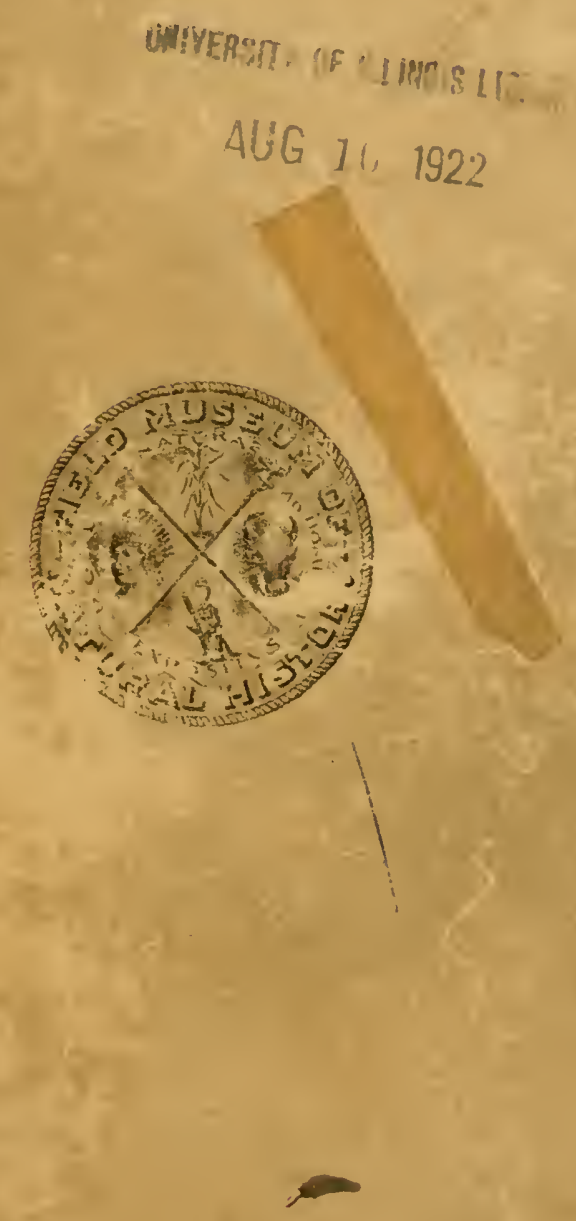

FIELD MUSEUM OF NATURAL HISTORY CHICAGO 


\section{THE UNIVERSITY}

* OF ILLINOIS

$$
\begin{gathered}
\text { LIBRARY } \\
590 \\
\text { F } 450 \\
\text { no.1-13 }
\end{gathered}
$$

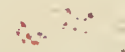




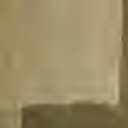

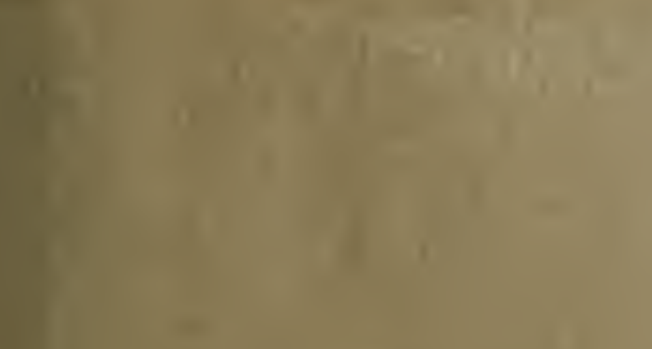

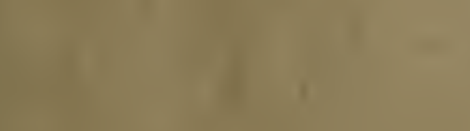

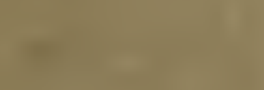

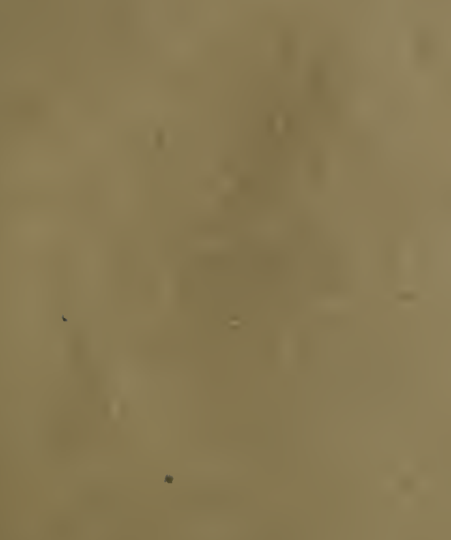

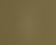

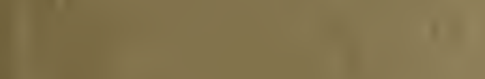



P. I 


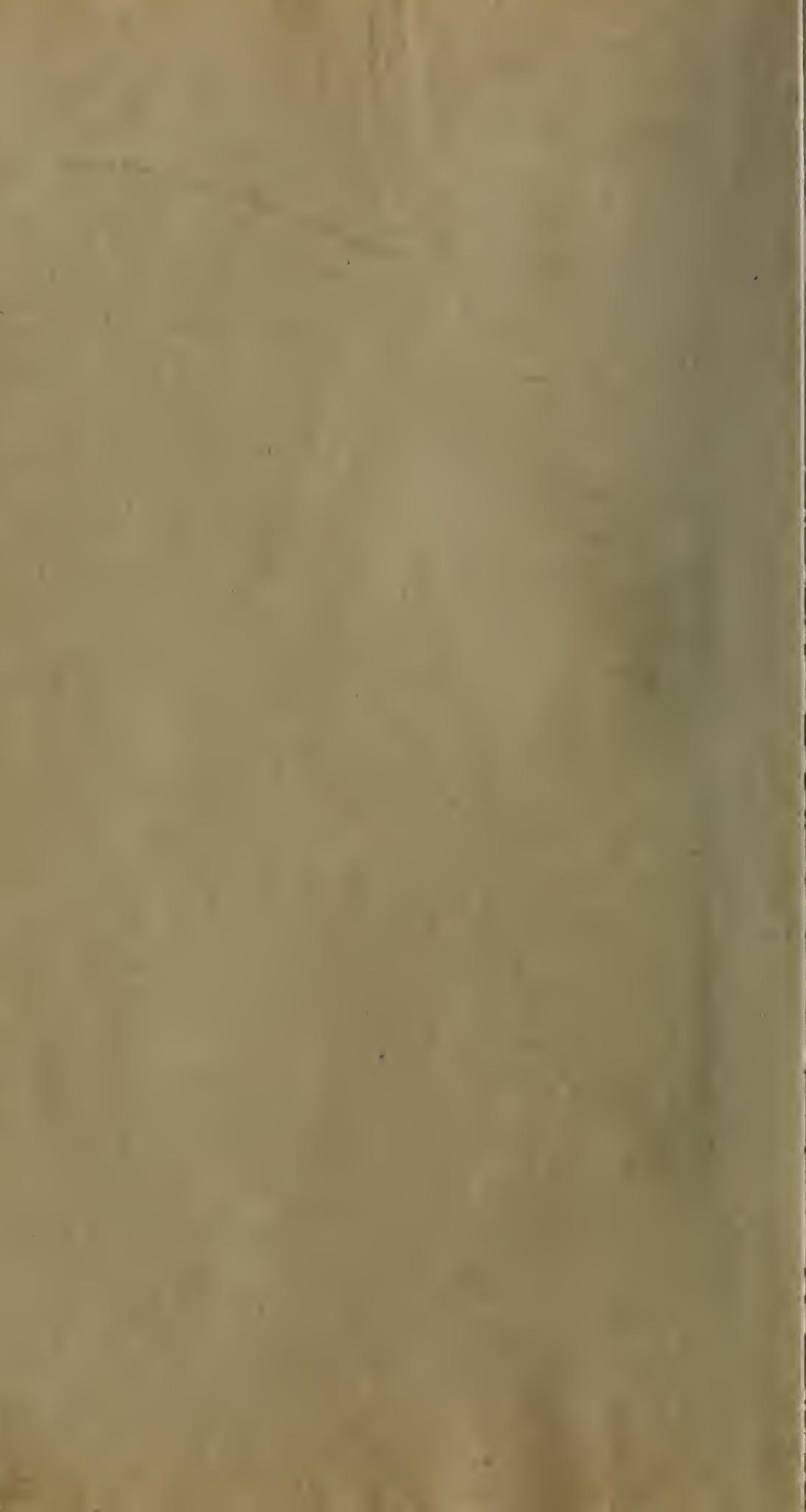


4.10

\title{
THE TRUTH ABOUT SNAKE STORIES
}

\author{
BY \\ KARL P. SCHMIDT \\ assistant Curator of Reptiles and Amphibians
}

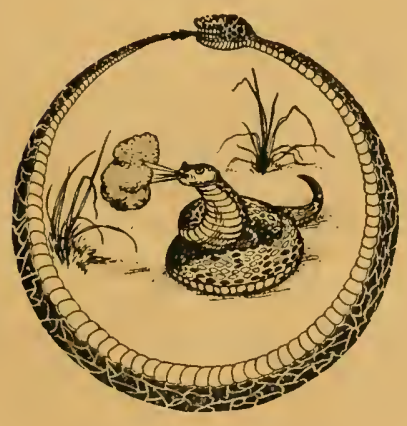

THE LWRARY GF THE

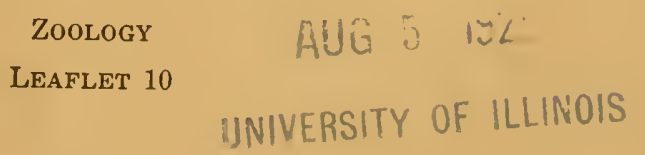

FIELD MUSEUM OF NATURAL HISTORY CHICAGÓ 1929 
The Zoological Leaflets of Field Museum are devoted to brief, non-technical accounts of the history, classification, distribution and life habits of animals, with especial reference to subjects shown in the Museum's exhibits.

\section{LIST OF ZOOLOGICAL LEAFLETS ISSUED TO DATE}

No. 1. The White-tailed Deer . . . . . . . . . $\$ .10$

No. 2. Chicago Winter Birds . . . . . . . . . 10

No. 3. The American Alligator . . . . . . . . 10

No. 4. The Periodical Cicada . . . . . . . . . .10

No. 5. The Alligator Gar . . . . . . . . . . $\quad .10$

No. 6. The Wild Turkey . . . . . . . . . . . $\quad .10$

No. 7. The Man-Eating Lions of Tsavo . . . . . $\quad .50$

No. 8. Mammals of the Chicago Area . . . . . . $\quad .25$

No. 9. Pike, Pickerel and Muskalonge. . . . . . $\quad .75$

No. 10. The Truth About Snake Stories . . . . . 20

STEPHEN C. SIMMS DIRECTOR 
Field Museum of Natural History

DEPARTMENT OF ZOOLOGY

Chicago, 1929

LEAFLET NUMBER 10

Copyright 1929 by Field Museum of Natural History

\section{The Truth About Snake Stories}

The real truth about snake stories is that they are all too likely to be untrue. The stories popularly believed about snakes are legion, and unquestionably the amount of misinformation current about them greatly exceeds what is known to the average man of the "truth about snakes." "Fish Stories" as a class are mere exaggerations, while reptile and snake stories are more fanciful or truly mythical elaborations of a much smaller foundation of fact. Many of the beliefs about snakes, and about reptiles in general, do have some original basis in observation. When critically examined, this modicum of truth may prove to be infinitesimal, or the observable facts may prove to have been wrongly interpreted.

The tenacity of life of such misinterpretations is often extraordinary. Herodotus ${ }^{1}$ relates of the crocodile that "it does not move the lower jaw, but is the only animal that brings down its upper jaw to the under one." This identical statement appears in the circular of a present day "Alligator Farm," in Florida, where it is cited as a means of distinguishing crocodiles from alligators. If one views an open-mouthed crocodile (or an alligator, for that matter) with entire oblivion to the facts of anatomy, it may indeed appear that the upper jaw is opened instead of the lower. The slightest observation, or even reflection, would prove that this is an appearance only, and that the lower jaws of crocodilians are hinged to the fixed remainder of the skull as obviously as in ourselves.

'Book II, section 68 . 
Had this story been told of snakes, it would have been partly true, for while all snakes open their lower jaws, most of them have also some power to move the toothbearing upper jaws. ${ }^{1}$ In the vipers, the maxillary bones are hinged to the skull and must be pushed forward to bring the poison-conducting fangs into action. This readily accessible item of information is not nearly as widely known as the wholly fabulous idea that snakes "sting with their tongues."

\section{The Treatment of Snake Bite}

In North America the sovereign remedy for snake bite is whisky, prescribed in large doses. A more extraordinarily wrong procedure could not well be devised. Thorough-going experiments have shown that alcohol in small doses increases the rapidity with which snake poison is absorbed by the body, while in larger doses it very rapidly becomes an active aid to the snake poison, weakening the heart action when it most requires stimulation.

The great majority of North American snakes are entirely non-poisonous. Several of the larger species however, the Common Black Snake and the large water snakes for example, are even more aggressive and more likely to bite than their poisonous brethren, a fact well known to most naturalists from personal experience. Such bites invariably heal promptly, without the slightest local or general symptoms of poisoning. To the great majority of people, however, all snakes are alike poisonous, and whisky has undoubtedly often been administered for the bite of such non-poisonous snakes. The patient, being less likely to die from the whisky alone than from the combination of whisky and snake poison, has a good chance of recovering in such cases. This chain of circum-

${ }^{1}$ Certain salamanders have the lower jaw really fixed and open the mouth by raising the head. 
stances forms the foundation of the popular faith in whisky as a remedy for snake bite, though it must also be admitted that the belief is one willingly entertained by many. It is no exaggeration to say that deaths from the "remedy," when administered for the bite of really poisonous snakes, exceed the total deaths from snake poisoning in North America.

The application of scientific research, beginning with the work of Pasteur, has developed the only real specifics against snake poison in the modern anti-venins. By their use, for example, the fatalities from snake poisoning in the Brazilian state of São Paulo have been reduced from the record of 155 in 1907 to two or three in 1924 . Unfortunately it has been found that specific anti-venins must be prepared for each species, or at least for each group of related species, of poisonous snakes; and this increases vastly the difficulties of treatment by this means. A North American anti-snake-bite serum has just been put on the market.

There is no reason to believe that the popular remedies for snake bite in other countries are of any greater value than the North American whisky, though probably few are so positively dangerous. The literature of this subject is an enormous one, and entirely beyond the scope of the present brief account of "Snake stories." The use of snakes, or parts of snakes, as Materia Medica is another department of snake-lore which must receive mere mention.

\section{RATTLESNAKE STORIES}

The most characteristic poisonous snakes of North America are the rattlesnakes, and an extensive folklore has grown up about them. Quite the most common belief about rattlesnakes is that their age may be told by the number of rattles they possess. This is true when the rattle is complete with the original button with which the 
snake was born, though the number of rattles varies with the amount of food taken by the snake, and certain other conditions, so that the average figure, three rattles per year, is subject to individual fluctuations. A rattle is added every time the skin is shed. When the snake is full grown the rattle is rarely complete.

It is widely believed that rattlesnakes when confined, and especially if tortured, will strike themselves and thus commit suicide. All available information, however, indicates that snakes are immune to their own venom, and in experiments I have made personally, causing a rattler to bite himself, there was no visible effect. There is a foundation for the story in the fact that a snake, if sufficiently excited, will lash out in every direction and may then catch his fangs on one of his coils. The Blow Snake, when going into the convulsion preceding its deathfeint, frequently catches its fangs on its own body.

The common belief in the South-west that rattlesnakes will not cross a horse-hair rope (or even a chalkline!) also seems to be without foundation.

One of the widespread beliefs about rattlesnakes in the West concerns their presence in prairie dog colonies, where they are said to live in peace with the prairie dogs and the burrowing owls. The peacefulness of this relation is certainly open to question, in view of the rattlesnake's fondness for small mammals as an article of diet.

By far the most characteristic North American rattlesnake fable is an elaboration of the fact that it is possible to be slightly poisoned by the venom in a broken fang. At its best, the story goes, a man was bitten by a rattlesnake and duly died therefrom. His infant son grows to manhood, and, finding an old pair of boots in the attic which fit him, puts them on and mysteriously dies with the symptoms of snake poisoning. An infant grandson grows up and, finding an old pair of shoes about, puts them on and becomes violently ill, but recovers. Ex- 
amination of the boots reveals the broken fang of a rattlesnake embedded in the leather. The number of generations in this story varies, but otherwise its general course is the same whether it is told in Florida, Texas, or California. It has recently been embodied in an excellently written short story. The amount of poison on the point of a fang is of course so small that fatal results are very unlikely.

\section{The Joint Snake}

In the Joint Snake story or the Glass Snake story, we are told of a curious snake which flies into pieces when struck with a stick. The pieces are said to reunite and craivl away if one leaves them undisturbed. This extraordinary story has a more extensive basis in fact than most of the popular snake myths. The fact that the Joint Snake is not a snake but a lizard is obscure to the ordinary observer, since it is entirely limbless and so has a snakelike form. It is, nevertheless, easily distinguished from the snakes by the presence of eyelids and ear-openings as well as by its small belly-scales and long tail. It is the length of the tail that is important to the story. Most lizards are able to lose their tails without serious injury and with the benefit that they are likely to escape while their enemies are dealing with the tail. In many lizards, among them the Joint Snake, this capacity to lose the tail is very highly developed. The tail breaks at a special breakage plane and the muscle bundles are so arranged that they expand and close the arteries, preventing the loss of blood. The tail, or the pieces of the tail, are furthermore endowed with a very active reflex motion which causes them to snap and squirm and jump so that they are very much more conspicuous than the lizard's body, which is engaged in making a quiet get-away. It is not true that the pieces will join together again but it is some compensation for the lizard that it is able to grow a perfectly satisfactory new tail. 


\section{Snakes Charming Their Prey}

In a fanciful American Indian fable the toad saves himself from his enemy, the snake, by the clever expedient of taking a stick in his mouth and facing his pursuer. The Indians, apparently, did not have the widespread belief in the ability of snakes to 'charm' their prey. In the full development of this belief, the snake's eyes so fascinate its bird or mammal victim that the unfortunate animal is made to advance toward the snake until it is drawn into the waiting jaws. It is possible that a small bird or mouse attacked by a snake might occasionally be unable to move from fright, but the behavior of mice when fed to caged snakes does not support even this hypothesis. Mice and rats invariably display the most complete indifference to the presence of a snake.

\section{SNake Charming}

Snakes themselves, however, may be 'charmed' in a somewhat different sense. The professional snake-charmer, with his assistants and a stock of snakes, is a familiar figure throughout the Orient. Quite the most mysterious element in this so-called snake-charming lies in the apparent response of the snakes to music. 'Deaf as an adder' is an old English adage, and the deafness of snakes in general seems to be supported by the most careful scientific experiment. In most cases, the swaying of the snakes in time to the music is due to the swaying of the body of the performer, and stops when he comes to rest. The snakes used in this practice are usually poisonous species, and the favorites are the cobras, which are preferred for their spectacular hood, their habit of raising the head and body, and their connection with Hindu mythology. Sometimes these poisonous snakes are defanged, sometimes their lips are sewed shut, and sometimes they are certainly not so treated, but remain in full possession of their poison-apparatus. It is likely 
that some of the professional snake-charmers are immune to the poison because of repeated small inoculations. An adequate study of oriental snake-charming from the scientist's standpoint remains to be made.

It is interesting that the removal of the poison fangs does not make a poisonous snake permanently harmless. The teeth of snakes are shed and replaced throughout life, and the poison-fangs are simply teeth modified into hypodermic needles for the injection of poison.

\section{Viviparous and Egg Laying SNakes}

Most reptiles lay eggs, but it is a curious and popularly much misunderstood fact that many snakes give birth to living young. In the reptile egg the growing embryo is nourished by a large food yolk. When the eggs are retained in the mother-snake's body, development takes place and eggs may be laid with embryos at various stages of advancement. In many snakes the development of the eggs in the body until the young snakes are fully formed has become the rule, and the young are then born alive. Since the young are nourished from an egg-yolk and not from the blood of the mother, this form of devellopment is distinguished as ovo-viviparity. In the Chicago Area, the commonest species of snakes, the garter snakes and water snakes, with their small allies, produce living young. This is also the habit of the only poisonous snake found near Chicago, the Prairie Rattlesnake or Massasauga. The egg-laying species are the Green Snake, Blue Racer, Milk Snake, Spotted Adder (or Fox Snake), and the Hog Nosed Snake. The eggs of snakes may usually be recognized by their elongate shape and leathery shell.

\section{THE FEAR OF SNAKES}

It is a widely held belief that the common aversion to snakes which amounts to violent fear in many persons, is instinctive in the human race. The evidence at my 
disposal leads me to the conclusion that this aversion and fear, when they exist, are wholly due to the example of an older person. I have never found any child who exhibited the slightest fear of snakes if he had not previously been frightened about them. On the average, in support of this observation, I find the fear of snakes much more frequent in older than in younger children. Anthropoid apes and, indeed, most monkeys, exhibit the same fear of snakes as is shown by man, but evidence exists to indicate that their fear is no more instinctive than the human. Drs. Mitchell and Pocock, of the London Zoological Society, experimented with the animals kept in the Zoological Gardens, and found that the great majority of the monkeys exhibited pronounced fear of harmless snakes which were shown to them. The behavior of the monkeys stood in marked contrast to that of all other mammals, including the lemurs (relatives of the monkeys), which were either indifferent to the presence of snakes or were merely curious about them. Some years later, remembering that a young chimpanzee had shown no fear, the experiment was repeated by offering a harmless boa to a chimpanzee which had been received at the Society's Gardens at a very early age. This youngster was not in the least afraid of the snake and, on the contrary, came to regard snakes as interesting playthings. Thus the 'instinctive' fear of snakes in monkeys appears to be based on the example of frightened adults exactly as it is in children.

\section{The Blow SNAKe}

Throughout eastern North America a snake is found which usually bears a most evil reputation. The number of popular names applied to it attest its abundance, and many of them indicate its bad character. It is known variously as "Hog Nosed Snake," "Spreading Adder," "Blow Snake," "Blowing Viper," and "Puff Adder." Terrifying tales are told of the way in which this snake 
actually blows its venom from a considerable distance into its victim's face, causing sometimes temporary blindness, sometimes convulsions. Although most of these stories are told at second hand, there is no dearth of actual eye-witness evidence of such poisonings.

As this snake is a common one in all sandy localities, there is no difficulty in checking up this reputation with actual observation of its behavior. In this case the facts turn out to be far more remarkable than the beliefs. As "Hog Nosed Snake" suggests, this species has a triangular, flattened head, with a sharp-pointed and slightly upturned snout. The shape of its head corresponds well with the rough diagnosis of poisonous snakes as "broadheaded." In fact, when the "Spreading Adder" spreads the bones of its jaws at the rear of the head, as it does when alarmed, the head is proportionately broader than that of any rattlesnake. In addition to flattening and widening the head, the whole anterior third of the body is strongly flattened, and raised from the ground. In this position the snake faces its enemy, a more formidable looking animal than an Indian cobra of equal size. The lungs are filled with air, the middle of the body becoming twice its normal size, and if the intruder approaches the snake it strikes and lunges viciously at him with open mouth and with loud hissing exhalations of the breath. In every action it is more aggressive and more dangerous in appearance than any poisonous snake of similar proportions.

However, this snake has apparently been infected with the "Great American Bluff." If one refuses to be frightened by this performance, advances upon the threatening reptile, and holds a finger within reach of its stroke, -it does not bite. The stories about the poisonous nature of its breath are evidently fictitious, for no effect on nose or eyes can be observed. If picked up, however, the nauseous secretion of the anal scent glands is emitted, 
and to an already frightened person, this odor might suggest a poisonous breath. Detailed examination of the anatomy of this snake, as well as direct observation, proves that it is entirely harmless.

If a snake of this species is still further molested, and especially if it be actually hurt, it gives up the whole repertoire of bluff and tries another dodge, the wellknown one of "playing possum." This it does with variations of its own. It writhes and squirms convulsively, opens its mouth, lets the tongue hang out, turns on its back, and ceases to move. It may now be poked or moved about, and is apparently a dead snake. In its reptilian mind, death and lying on one's back are evidently synonymous, for if one turns the snake over on its belly, it instantly turns back again to lie on its back, as if to demonstrate before one's eyes that it is veritably dead. If one sits still and watches, after a few minutes the snake's head will be raised to see if the coast be clear, and if no move is made, it rights itself and promptly attempts to escape. If the observer makes a move, the attitude of death is promptly resumed.

That this behavior may successfully delude a competent observer is seen in the account of this reptile by J. H. Hinton". "The brown viper or hissing snake is of a dirty brown color, from six to eight inches long, with a body large in proportion and terminating abruptly in a sharp tail: when angry their heads flatten and dilate to twice the common extent, and their hiss is like that of a goose. They are extremely ugly animals: and though very diminutive, are supposed to be of the most venomous class. One being confined with a stick across its back, it instantly bit itself in two or three places; and when set at liberty it soon became very much swollen, and died."

${ }^{1}$ History and Topography of the United States. London, vol. II, p. 185,1832 . 
The "Blow Snake" stories are fables in eastern North America, but in Africa similar stories about really poisonous snakes are perfectly true. One of the African cobras, a common species in North-east Africa, spits its poison with evident aim at the face of an approaching enemy, and this poison causes violent inflammation of the eyes if it reaches them. A near relative of the cobras, the "Ringhals" or "Spuyslang" of South Africa is an even more inveterate spitter, and captive specimens have been known to keep the glass fronts of their cages sprayed with poison.

\section{The Hoop SNake}

Another cycle of snake myths peculiar to North America relates to the Hoop Snake. The various Hoop Snake stories are told with so much gusto, and are embroidered with such incredible details that they seem more like "tall stories" designed for the edification of the tenderfoot than like genuine beliefs, held by otherwise sane persons.

The best-known version of this story tells of a large snake that progresses by taking its tail in its mouth and rolling like a hoop. The tail is said to be provided with a venomous sting, and the snake is capable of launching itself like a javelin, tail foremost, at an enemy. A wound by the tail-sting is almost instantly fatal, and the poison is so virulent that trees, accidentally struck by this snake, immediately wither and die. The force of its blow is such that a snake of this species has been known to strike its tail so violently into a tree as to be unable to disengage itself.

The background for this terrifying story is found in the much more widely held belief in a snake that stings with its tail, usually referred to as the "Stingin' Snake" or "Horn Snake." This, in turn, is based on the behavior of certain snakes when held in the hand or even 
when confined with a stick, which make exploring or apparently pricking movements with the tip of the tail. When, in addition, the tail ends in a sharp horny spine, some excuse is afforded for the belief in a tail-sting. The truth is, however, that no matter how much the tail of a snake may appear like a sting or even act like a sting, no snake has a poisonous or dangerous weapon in its tail. This fact is of course easily demonstrated by a person who happens not to fear harmless snakes, but such a person will frequently be taxed with the possession of cccult or special powers which render him immune. The elaborations of stories of a stinging snake into accounts of a snake that rolls like a hoop are of course entirely fabulous.

\section{The Milk SNake}

Two snake myths are apparently quite universal, the one to the effect that snakes, frequently some particular species of snake, suck milk from cows, and the even more startling belief that young snakes take refuge in their mother's throat when alarmed or in danger. Both of these stories are supported by an enormous mass of evidence from eye-witnesses. The two stories represent very different types of myths, the first being physically impossible, while the second is at least not impossible.

It is not difficult to establish an hypothesis for the origin of the Milk Snake story. Cows are liable to sudden variations in milk flow from a large number of natural causes. This variation is a subject of importance to the cow's owner, and a matter of frequent observation, while the true causes of the failure of the milk flow are often obscure and rarely observable. With this mental background, if a species of snake were found to frequent barns or pastures; and if an individual snake were to be seen to drink milk from the cat's saucer, or to drink the milk leaking from a cow's distended udder, 
a causal connection between the presence of the snakes and the fluctuations in milk flow might be suspected. The snake most often credited with this performance, and known, in fact, as the "Milk Snake" (Lampropeltis triangulum, in eastern North America), fulfills the requirement of frequenting barns; and as snakes all drink water, it is not at all unlikely that they would drink milk on occasion. For that matter the country people in India are said to set out a saucer of milk for the cobra which frequents their premises.

It has been suggested that some of the egg-laying snakes frequent manure-piles and compost-heaps about barns for the purpose of laying their eggs. Most farmers, when they kill a snake, do so with such blind zeal and fury that little of the victim is left. The crushed eggs of a gravid snake would give forth a milk-like fluid, and this might be observed as confirmatory evidence for the belief in their ability to suck cows.

The ability of any snake to fasten itself to a cow's udder and suck milk must be considered a plain impossibility. If the six rows of needlelike recurved teeth in a snake's mouth were applied to a cow's sensitive teat, the animal would be driven into a frenzy, and the snake would be promptly dislodged by being kicked or stepped upon.

The Milk Snake frequents barns for the mice which are its favorite prey. It is one of the most gentle and useful of all North American snakes. Its bite, if it could be induced to bite, would be absolutely harmless, no more dangerous than a few pricks or scratches from sterile needles, and not a fraction as dangerous as the bite of a mouse or rat. In western North America, the abundant gopher snakes (Pituophis spp.) are taxed with sucking cows. In other lands, other species of snakes are singled out as "carriers" for the myth. A singular variant ap- 
pears in Brazil, where certain snakes are thought to frequent the huts of the Indians at night for the milk of the human mothers.

\section{Mother Snake Swallowing Young}

The attractive story that the mother snake receives her young into her throat to protect them from danger is apparently not physically impossible. The "snakeswallowing-young" story is supported by such plausible published accounts, some of them apparently so credible, that even reputable herpetologists maintain, or endeavor to maintain, an open mind on this particular question. It has been objected that the young would immediately suffocate, or that they would be attacked by the gastric juices; but snakes do not suffocate very promptly, and there is a goodly stretch of gullet before the snake's stomach begins.

A second line of attack on the validity of this story rests on the possibility of a misinterpretation of perfectly correct, though hurried, observation. Many species of snakes, and among them the very ones to which the story is most frequently attached, give birth to living young. For several days before their actual birth these snakes are fully formed and capable of motion. As I have indicated above, snakes are commonly killed with brutal violence, and a gravid viper or garter snake or rattlesnake might then be seen to contain actual living young. No ordinary person takes the trouble to distinguish between one internal organ and another, in a snake at least, and an observer of the facts outlined above, especially if already familiar with the "snake-swallowingyoung" story, would doubtless become an active witness for the truth of the belief.

Miss Joan B. Procter, of the London Zoological Society, suggests another bit of observation which might be misinterpreted. The common English snakes frequent- 
ly feed on lizards, and the tails of their prey would be seen to wriggle as they disappeared down the snake's throat. Numerous snakes are snake-eaters, and on some occasions such snakes might be found to contain one or more other snakes when killed.

The most conclusive objection to the truth of the story is that the occurrence has never been observed in the London or New York Zoological Gardens, where thousands of snakes have been kept alive, and where hundreds of broods of young snakes must have been born. In captivity, such young snakes would be confined to the box with their mother, while in nature, there is no evidence independent of the stories in question to show that the young snakes remain with their parent at all. A. priori the story seems improbable. It bears all of the ear-marks of a "snake story," even to the abundance of eye-witness evidence. Altogether, it is overwhelmingly improbable.

Against this improbability must be set the frequently detailed accounts of numerous observers, among whom are men of education and even a few scientists, and the vast popular conviction that the story is true. No story is more universally known. Milton's guardian of the gates of Hell seems evidently based upon it or upon some classical version which would carry the story still farther back in time.

I can do no better than to quote the most convincing of the accounts known to me, and leave the reader with the hope that so charming a story may yet be proved true, to the confusion of skeptics and unbelievers.

"The country school in Iowa which the writer" attended was held in the ordinary frame schoolhouse supported by a 'cobblestone' foundation of water-worn rocks more or less embedded in mortar. The school-

IE. D. Ball, writing in the Proceedings of the Iowa Academy of Science. Vol. XXII, pp. 343-344. 
house faced the south and a set of narrow steps led up to the single central door. Through the foundation wall about halfway between these steps and the southeast corner of the building, and about eight to ten inches above the surface of the ground, was an irregular opening about two inches in diameter. This opening was used as a refuge one spring and summer by a large and motherly looking specimen of the common garter snake of the region. The snake kept close to the hole at first and disappeared at the slightest sound. Later as we became interested in it, it was not disturbed and became accustomed to the ordinary noises of the children and would, if not too closely approached, often lie in the sun alongside the wall during recess time. One day as we came trooping out at noon the snake raised its head several inches from the ground, uttered a hissing sound and then lowered its head to within an inch or two of the ground and opened its mouth quite widely. This rather frightened us and all eyes were on the snake, when from around the corner of the house and from further away in the yard came a number of small snakes which rushed pellmell into the open mouth of the mother. When the last one was in, the mother snake raised her head quite high, wriggled over to the hole and disappeared. She was back there again at the next recess and the performance was repeated for a number of days. After this the same thing occurred at each recess, and two of us, who had even then budding naturalistic instincts, would occasionally ask to go out in order to get a performance for our special benefit.

"When the troops of children were pushing and elbowing to see, they would crowd up within a few feet of the snake, and the performance was very hasty and the snakes' disappearance rapid-the whole occupying only a few seconds. When, however, we went out alone and were careful not to get too near at the start, the mother snake would of ten not go into the hole at first but simply 
raise her head and remain in that position for several minutes, or until our curiosity prompted us to approach too close, when she would go in rather leisurely.

"At these times the first little snakes to enter the mouth would almost instantly turn around and stick their little heads out and thrust out their forked tongues as defiantly as you please. Often there would be three or four of these heads sticking out at one time, and considerable signs of a rumpus going on inside her body a few inches back from the head. These signs we interpreted as the other little snakes fighting for a chance to get their heads out.

"The little ones never seemed to be far away and often would be lying alongside the mother. The hiss seemed to be the sign for them to scurry for the mouth, and often two or three would be entering at the same time, while frequently before the last one was in there would be one or more heads sticking out. We never saw a little snake come entirely out, for as soon as the last one started in the mother snake would raise her head quite high, higher than that species ordinarily carries its head. The bulge in the mother snake was always in that part above ground, and there was always considerable movement in the bulge.

"There could be no possibility of an optical illusion through the small snakes' going under the mother, because as soon as they were in, the head was always raised higher than the length of the little snakes and their heads and often an inch of their bodies would be showing out of the mouth at this time. Moreover the hole the mother's body went through was a tight fit around the bulge so that no little snakes could have gone in outside the mother, even if they could have reached up to the hole, which they could not. And if they were going into the hole at all why go past it as they often did to reach the mother's mouth? This same performance has been wit- 
nessed several times since under less satisfactory conditions, but at the time no question had been raised in the writer's mind and no particular attention was paid the details."

As Dr. Ball is one of the leading entomologists of the United States, his account of this phenomenon is evidently not only the most interesting but one of the most convincing. But for his last sentence, and the fact that the story is told as a memory of an event many years past, it could be accepted as the conclusive proof for which students of reptiles must still wait.

In the face of accounts so plausible and so detailed, 'rationalistic' explanations of the supposed observations are evidently worthless. Snake stories of this type are true myths, all the more interesting because they are alive and growing, and herpetologists may resign the study of this field to their anthropological brethren with the hope that it may produce valuable insights into the nature of mythology and folklore.

KARL P. SCHMIDT,

Assistant Curator of Reptiles and Amphibians. 
BOOKS AND ARTICLES ABOUT SNAKE STORIES

Ditmars, Raymond L.......The Reptiles of the World. (New York, 1910).

Mitchell, P. Chalmers and

Pocock, R. I............ On the Feeding of Reptiles in Captivity. With Observations on the Fear of Snakes by other Vertebrates. (Proc. Zool. Soc. London for 1907, pp. 785-794, 1907).

Mitchell, P. Chalmers......Monkeys and the Fear of Snakes. (Proc. Zool. Soc. London for 1922, pp. 347-348, 1922).

Noble, G. K........... Do Snakes Swallow Their Young for Protection? (Copeia, No. 98, pp. 54-57, 1921)-With a bibliography of this subject.

LANE, Rose Wilder. . . . . . Y Yarbwoman. (Harpers Magazine, vol. 155 , pp. 210-221, 1927). The story of the rattlesnake fang in a boot employed for literary effect.

SchMIDT, KaRL P........The Hoop Snake Story. (Natural History, vol. 25, pp. $76-80,1925)$. An historical and critical account of the hoop snake myth.

SpEck, Frank G.........The Origin of the Belief that Snakes Swallow Their Young for Protection. (Copeia, No. 98, pp. 51-54, 1921).

Strecker, John K........ Reptile Myths of Northwestern Louisiana. (Publ. Texas Folklore Soc., vol. 4, pp. 44-52, 1925.

Reptiles of the South and Southwest in Folklore. (ibid., vol. 5, pp. 56-69, 1926).

On the Origins of Reptile Myths. (ibid., pp. 70-77, 1926).

VANDERCOOK, JoHN W......White Magic and Black. (Harpers Magazine, vol. 151, pp. 546-554, 1925). Contains an account of the most potent remedy for snake bites thus far reported.

\section{THE Lerhary Go The}





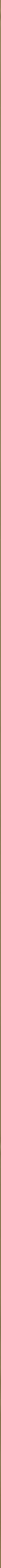





UNIVERSTY OFILUNOIS-UABANA |||||||||

30112037878243 